UCRL-ID-121178

\title{
Calculations of Fluid-Mineral Equilibria in the Äspö Hard Rock Laboratory
}

\author{
C.J. Bruton
}

May 1995

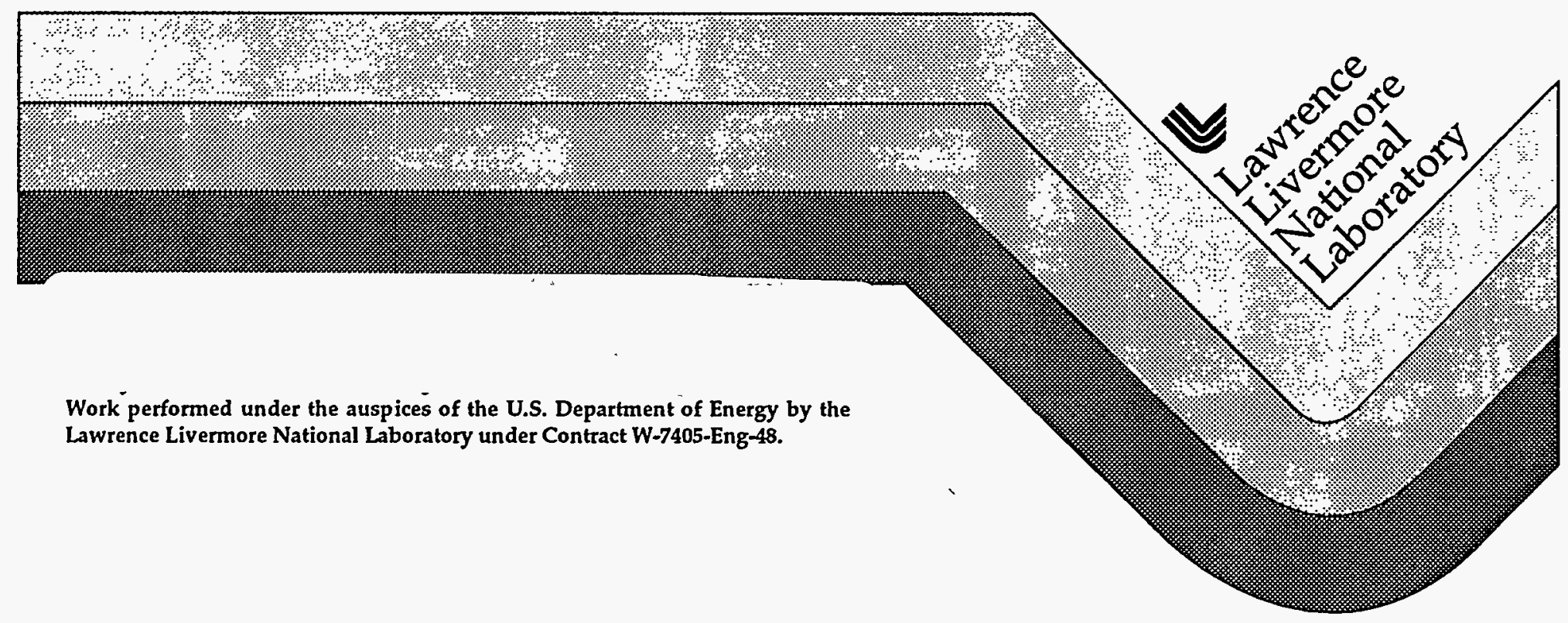




\section{DISCLAIMER}

Portions of this document may be illegible in electronic image products. Images are produced from the best available original document. 


\title{
Calculations of Fluid-Mineral Equilibria in the Äspö Hard Rock Laboratory
}

\author{
Carol J. Bruton \\ Lawrence Livermore National Laboratory \\ Livermore, California 94550 \\ USA
}

\section{Introduction}

The purpose of this report is to evaluate the utility of the EQ3/6 geochemical codes (Wolery, 1992; Wolery and Daveler, 1992) in describing mineral-fluid equilibria in the low temperature $\left(<25^{\circ} \mathrm{C}\right)$ systems at the Äspö Hard Rock Laboratory (HRL). Data on fluid chemistry and on fracture-filling mineralogy with depth were obtained from Smellie and Laaksoharju (1992). Average temperatures in the HRL boreholes are generally less than $20^{\circ} \mathrm{C}$. EQ3/6 was used to evaluate the extent to which equilibrium is achieved between minerals and fluids in these systems.

Smellie and Laaksoharju (1992) used the PHREEQE geochemical modeling code to calculate saturation indices for fracture-lining minerals in boreholes KAS02, KASO3, KASO4 and KAS06 in order to "support the presence or absence of the major fracture minerals". They noted that only calcite and gypsum may be expected to attain equilibrium under the low temperature conditions at Äspö. However, they used closeness to equilibrium as an indicator of "stable conditions, long bedrock residence/reaction times and slow to stagnant flow in the system." EQ3 (Wolery, 1992) was used to calculate mineral saturation indices for comparison, and EQ6 (Wolery and Daveler, 1992) was used to try to predict the mineral assemblages coexisting with fluids.

\section{Fluid chemistry}

Fluid analyses from boreholes KAS02, KAS03, KAS04 and KAS06 from Smellie and Laaksoharju (1992) were used in the EQ3 simulations. Waters that were categorized as both representative and not representative in Table A from Smellie and Laaksoharju (1992) were included. As will be shown below, some of the contamination in the "not representative" samples may be sufficiently small that its impact on computed rock-fluid equilibria may be insignificant.

The initial EQ3 runs were made assuming that the measured redox potential represented a condition of homogeneous redox equilibrium throughout the system. Measured $\mathrm{SO}_{4}$ concentrations were input as total sulfur, neglecting measured $\mathrm{S}^{-}$concentrations in the preliminary calculations. Measured $\mathrm{SO}_{4}$ concentrations greatly dominated measured $\mathrm{S}^{-}$ concentrations.

A number of the fluid analyses lacked Eh values. In KASO2, the Eh values for the 308-344 and 314-319 m samples were assumed to equal $-260 \mathrm{mV}$, and that of the $802-924 \mathrm{~m}$ sample was assumed to equal $-320 \mathrm{mV}$. In $\mathrm{KASO3}$, all missing values were assumed to equal 
$-270 \mathrm{mV}$. In KAS06, all values were assumed to equal $-300 \mathrm{mV}$. The spread of all measured Eh values was only $70 \mathrm{mV}$. These Eh values sometimes result in calculated $\mathrm{HS}^{-}$concentrations greater than $\mathrm{SO}_{4}^{--}$concentrations. The analyzed total organic carbon content of the waters was not considered in the simulation input.

Total $\mathrm{Al}$ concentration was assumed to equal $0.04 \mathrm{mg} / \mathrm{kg}$ in all waters. This value represents an approximate average of waters from all boreholes with measured $\mathrm{Al}$ obtained from the GEOTAB data base. No Al analyses were reported in Table 6.3 from Smellie and Laaksoharju (1992) from which all other water properties were obtained. Computed charge balances for these waters were excellent, as noted by Smellie and Laaksoharju (1992).

Temperature in all EQ3 and EQ6 simulations was assumed to equal $15^{\circ} \mathrm{C}$.

\section{Calculation of saturation indices: comparison between PHREEQE and EQ3 results}

Saturation indices $(\log \mathrm{Q} / \mathrm{K})$ calculated with $\mathrm{EQ} 3$ and version comR16 of the GEMBOCHS data base were compared to those computed using PHREEQE and plotted as histograms in Smellie and Laaksoharju (1992) for boreholes KASO2, 3, 4 and 6. Exact comparisons were not possible because of uncertainties in how Smellie and Laaksoharju (1992) set the temperature, Al concentration and the redox state of the system, as well the unavailability of tabular data in their report. Differences between thermodynamic data in GEMBOCHS and the PHREEQE data base may also account for discrepancies in computed saturation indices. The contents of the two data bases were not compared in this report. Nonetheless, results from borehole KAS02 will be used to focus on the similarities and differences between the EQ3 and PHREEQE simulations.

Quartz is close to saturation or supersaturated in all waters from KAS02 whether calculated using PHREEQE or EQ3. Quartz solubility data from both Walther and Helgeson (1977) and Fournier (1983) are used in EQ3. Smellie and Laaksoharju (1992) predicted supersaturation with respect to fluorite at all depths, whereas EQ3 calculates undersaturation in the samples from 200 to $500 \mathrm{~m}$, and near-equilibrium in the $800 \mathrm{~m}$ samples. Calcite is predicted to be supersaturated by both codes; calculated saturation indices are similar. Results for dolomite are roughly similar. Gypsum indices can be very different, although undersaturated or close to saturation in all cases. Tremolite is variably over- and undersaturated in both codes. PHREEQE predicts large supersaturations with respect to low albite, muscovite and laumontite (see also GEOTAB data base; Laaksoharju, 1993) as does EQ3. However, their calculated indices may differ by 1 or 2 orders of magnitude.

The GEOTAB data base (Laaksoharju, 1993) shows that in KAS02, hematite and goethite saturation indices tend to be low when pyrite's are high, and vice versa. Saturation indices from EQ3 suggest that Fe-bearing minerals are undersaturated in the 202 and $308 \mathrm{~m}$ samples, owing largely to the lower $\mathrm{pH}$ of the waters. At $802 \mathrm{~m}$ and deeper, Fe-bearing phases are undersaturated owing to lower measured Fe concentrations. It appears that disequilibrium exists between the fluids and the observed fracture mineral hematite which may be a remnant of an earlier hydrothermal event (Smellie and Laaksoharju, 1992). However, EQ3 
suggests that goethite is saturated in the $463 \mathrm{~m}$ sample, and supersaturated with respect to goethite as well as hematite in the $314 \mathrm{~m}$ sample. In the $530 \mathrm{~m}$ sample, fluid chemistry would be consistent with equilibrium with a phase(s) whose solubility lies between those of hematite and the more soluble goethite.

The most prominent differences in saturation indices computed using PHREEQE and EQ3 involve redox-sensitive minerals such as pyrite and gypsum. The differences probably result in large part from differences in the redox state set in the simulation input. Even when reported sulfide and sulfate concentrations are used, saturation indices computed for pyrite using EQ3 and PHREEQE are far apart. Indices for Fe-hydroxide and hematite also differ significantly. EQ3 saturation indices for pyrite and other phases, including aluminosilicates, more closely correspond to those listed in the GEOTAB data base than those in Smellie and Laaksoharju (1992). It is unknown why the indices for pyrite are so different in Smellie and Laaksoharju (1992) and GEOTAB.

\section{Analysis of saturation calculations}

Studies of mineral-fluid equilibria at temperatures about $250^{\circ} \mathrm{C}$ revealed that quartz equilibrium was maintained, and that the solubility of quartz as described by Fournier (1983) better described observed silica concentrations than data from Walther and Helgeson (1977). In contrast, calculations using the Äspö waters suggest that quartz equilibrium is not maintained in low temperature $\left(<25^{\circ} \mathrm{C}\right)$ systems. At Äspö, the shallowest samples have the highest $\mathrm{Si}$ concentrations, which suggests that silica concentrations in solution are probably not controlled by thermodynamic equilibrium with quartz. Irreversible mineral dissolution has added to the dissolved load of the waters, but the waters do not seem to have achieved partial equilibrium with a set of secondary precipitates.

Quartz solubility in the KAS02 waters calculated using either data from Fournier (1983) or Walther and Helgeson (1977) generally underestimate the amount of $\mathrm{Si}$ in solution at all depths for temperatures less than $25^{\circ} \mathrm{C}$. For example, at $10^{\circ} \mathrm{C}$, predicted $\mathrm{Si}$ concentrations in solution equal 2.2 and $1.5 \mathrm{mg} / \mathrm{kg} \mathrm{Si}$ according to Fournier (1983) and Walther and Helgeson (1977), respectively. Measured concentrations range from 2.0 to 6.1 .

Rates of processes are probably sufficiently slow at the low $\left(<25^{\circ} \mathrm{C}\right)$ temperatures in these systems that ion exchange and the kinetics of irreversible mineral dissolution rather than the equilibrium precipitation of secondary phases control observed elemental concentrations. Computer codes like EQ3/6 do not adequately predict mineral-fluid relations in some soil systems because of the complex and dynamic, kinetically controlled mass transfer among the solid, liquid, gas, solid/liquid interface, and biotic "reservoirs" that define these low-temperature, near-surface environments. Solid/liquid interface reactions (e.g. ion exchange, surface complexation) and biologically mediated transformations of carbon, nitrogen and sulfur compounds can only be partially simulated using EQ3/6. Unless codes provide for solid/liquid interface reactions, they will not produce satisfactory results. For example, Viani and Bruton (1994) showed that ion exchange can account for observed discrepancies in major cation concentrations predicted by conservative models of fluid mixing in the Äspö Hard Rock Laboratory. 
If irreversible dissolution of the fracture minerals controls solution composition and limited solid precipitation occurs to decrease elemental concentrations in solution, the solution could become supersaturated with any number of phases, including aluminosilicates, as observed in the Äspö waters (see below). Combined with the probability that ion exchange and surface reactions are going on, as well as fast-occurring redox reactions, current geochemical models cannot be expected to predict solution chemistry. They can, however, be used to try to identify and evaluate the reactions that produce observed solution compositions.

Researchers (e.g. Helgeson, Garrels and MacKenzie, 1969) have proposed that irreversible mineral dissolution and secondary phase precipitation occurring in partial equilibrium can account for observed fluid chemistry in some near-surface waters. However, further research demonstrated the importance of surface reactions such as ion exchange on fluid chemistry. Surface reactions can occur much faster than silicate mineral dissolution at low temperature. As Smellie and Laaksoharju (1992) point out, saturation indices for carbonates and sulfates may be the only ones that may represent equilibrium at Äspö. It therefore seems unwise to try to explain variations in water chemistry by mineral dissolution and precipitation alone in these systems.

\section{Correspondence with fracture mineralogy}

Fracture-filling minerals observed in KAS02 include quartz, calcite, epidote, chlorite, fluorite, hematite, $\mathrm{Fe}$-oxyhydroxides, pyrite, and clay minerals such as illite, montmorillonite and kaolinite. Prehnite and zeolites such as laumontite occur sporadically (Smellie and Laaksoharju, 1992). Some of these minerals (e.g. laumontite, epidote, hematite) are reflective of a past hydrothermal event, and are probably metastable in present-day waters.

Smellie and Laaksoharju (1992) stated that quartz, fluorite, pyrite and laumontite occur as fracture minerals at Äspö, and are also predicted by PHREEQE to be close to equilibrium or supersaturated in waters from KAS02. Gypsum was calculated to be undersaturated in all waters by PHREEQE, but small amounts are found in the fractures. Pyrite occurs sporadically in fractures. Smellie and Laaksojarju's (1992) calculated saturation indices for pyrite vary between super- and undersaturated, whereas $\mathrm{EQ} 3$ predicts supersaturation with respect to pyrite at all depths.

A complete examination of predicted saturation indices in $\mathrm{EQ} 3$ indicates that many minerals, including many silicates, aluminosilicates and $\mathrm{Fe}$-bearing minerals, are predicted to be significantly supersaturated in the Äspö waters at all depths. While quartz, fluorite, pyrite and laumontite may be supersaturated, so are any number of other silicates, such as Kfeldspar, albite, tremolite, epidote, prehnite and muscovite. Thus, PHREEQE and EQ3 results cannot be used to identify a unique mineral assemblage in contact with the fluids which controls their chemistry. In addition, some of the observed fracture-filling minerals are remnants of a past hydrothermal event, and are thus not expected to be in equilibrium with present-day waters.

Given the great number of phases that are supersaturated in the Äspö waters, the computer code EQ6 was used to see if it would select a secondary mineral assemblage in keeping 
with the observed fracture mineralogy. A correspondence would suggest fracture mineral/ fluid equilibrium or, in this case, metastability. During this process, EQ6 selects phases that are most supersaturated, and precipitates them one by one until a stable mineral assemblage is produced. The fluid chemistry changes during this process, so it is no longer representative of downhole fluid compositions. This exercise is designed to test the use of EQ6 in identifying potential metastable phase assemblages.

Predicted secondary mineral assemblages for borehole KASO2 are shown below.

202-214.5m - quartz, pyrite, calcite solid solution, mesolite, graphite 308-344 m- quartz, pyrite, calcite solid solution, mesolite, fluorapatite

314-319 m - quartz, pyrite, calcite solid solution, mesolite, fluorapatite, dioctahedral smectite 463-468 m - quartz, pyrite, calcite solid solution, mesolite, fluorapatite 530-535 m - quartz, pyrite, calcite solid solution, mesolite, fluorapatite, trioctahedral saponite

802-924 m - quartz, pyrite, calcite solid solution, trioctahedral saponite 860- $924 \mathrm{~m}$ - quartz, pyrite, calcite solid solution, trioctahedral saponite, talc, fluorite

Mesolite is one of a number of zeolites whose thermodynamic data come from Johnson and co-workers (see e.g., Johnson et al., 1992). However, this data set seems to consistently overestimate zeolite stability relative to other aluminosilicates, despite referencing the thermodynamic properties of zeolites to $\alpha$-quartz rather than silicalite (Viani and Bruton, 1992). When mesolite is prevented from precipitating in the simulation, the zeolite stilbite forms in its stead. However, usage of the stilbite data is subject to the same uncertainty as mesolite. Suppression of both mesolite and stilbite in the fluids produced a precipitate of kaolinite. Suppression of kaolinite in turn produced muscovite. Kaolinite and muscovite, the latter sometimes considered a proxy for illite, are perhaps more realistic choices for an Al-bearing precipitate in these systems.

The calculated calcite solid solutions are dominated by $\mathrm{Ca}$, with minor amounts of $\mathrm{Sr}, \mathrm{Mg}$ and $\mathrm{Mn}$. Dolomite was suppressed from precipitating in the simulations because it is inhibited from forming under these conditions in nature. The exchangeable cations of the dioctahedral smectites and trioctahedral saponites occur in the proportion $\mathrm{Ca}>\mathrm{Na}>\mathrm{Mg}$. When phosphate is listed explicitly in the chemical analysis, the fluorine is sequestered by fluorapatite. In the absence of phosphate in the $860 \mathrm{~m}$ sample, fluorite precipitates instead of fluorapatite.

Despite the evidence from saturation indices that the Äspö waters are not in partial equilibrium with fracture-lining silicate minerals, the above results suggest that EQ6 can be used to identify a likely metastable phase assemblage whose component minerals are actually supersaturated with respect to the borehole waters. Predicted mineral assemblages seem to be in fair agreement with fracture-lining mineralogy in KAS02. 


\section{Changes in fluid chemistry with depth: ion activities}

The observed and predicted mineral precipitates listed in the previous section do not change greatly with depth. Predicted saturation indices do not vary greatly with depth because of the limited variation of ion activities with depth. For example, Figure 1 shows

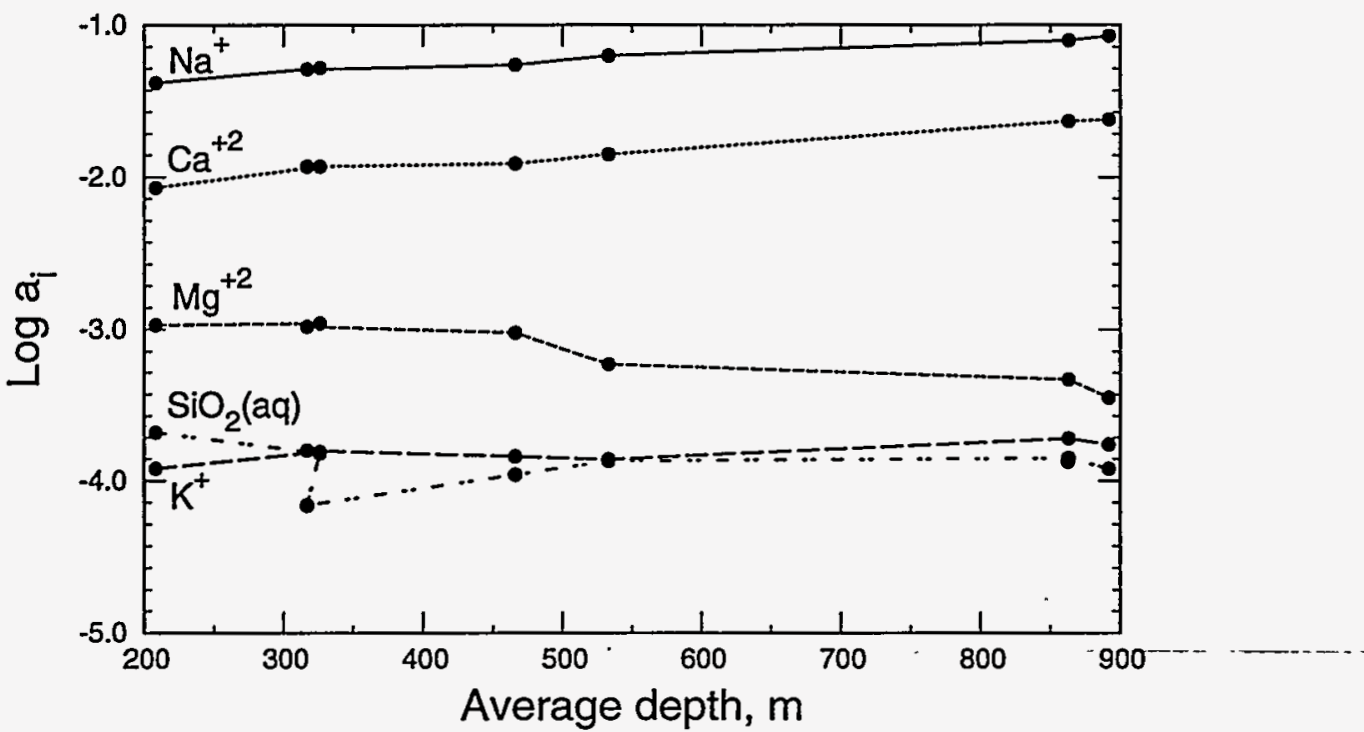

Figure 1. Logarithm of ion activities as a function of average depth of water sample in borehole KAS02.

the activities of $\mathrm{Na}^{+}, \mathrm{K}^{+}, \mathrm{Ca}^{++}, \mathrm{Mg}^{++}$and $\mathrm{SiO}_{2}(\mathrm{aq})$ in borehole $\mathrm{KASO} 2$ with depth. When plotted on a logarithmic scale, variations in elemental concentration with depth are damped.

Plots of the logarithm of the ratio of cation activities to hydrogen activity in borehole KASO2 (Figure 2) show relatively minor changes throughout the depth range as well, except for the shallowest samples. Much of the variation that does occur results from variations in $\mathrm{pH}$. In $\mathrm{KASO2}$, for example, variations in the activity ratio result when $\mathrm{pH}$ increases from 7.6 to 8.2 at about $310 \mathrm{~m}$, and from 8.2 to 8.5 at about $900 \mathrm{~m}$.

The constancy of activity ratios is representative of boreholes KAS03, KASO4 and KAS06 as well (Figures 3 through 5). Even though the cation concentrations increase with depth, the activity ratios change little. Therefore, computed mineral equilibria change little with depth, with the dominant control being changes in $\mathrm{pH}$. As Smellie and Laaksoharju (1992) note, $\mathrm{pH}$ is, unfortunately, one of the variables most affected by borehole activities.

In all KAS boreholes, the major cation chemistry of the "not representative" water samples do not significantly deviate from the major cation chemistry of the representative samples. One could not tell from examination of Figures 2 through 5 which of the samples were representative and which were not. Therefore, mineral assemblages predicted using "not representative" water samples would not differ significantly from those predicted using representative waters. 


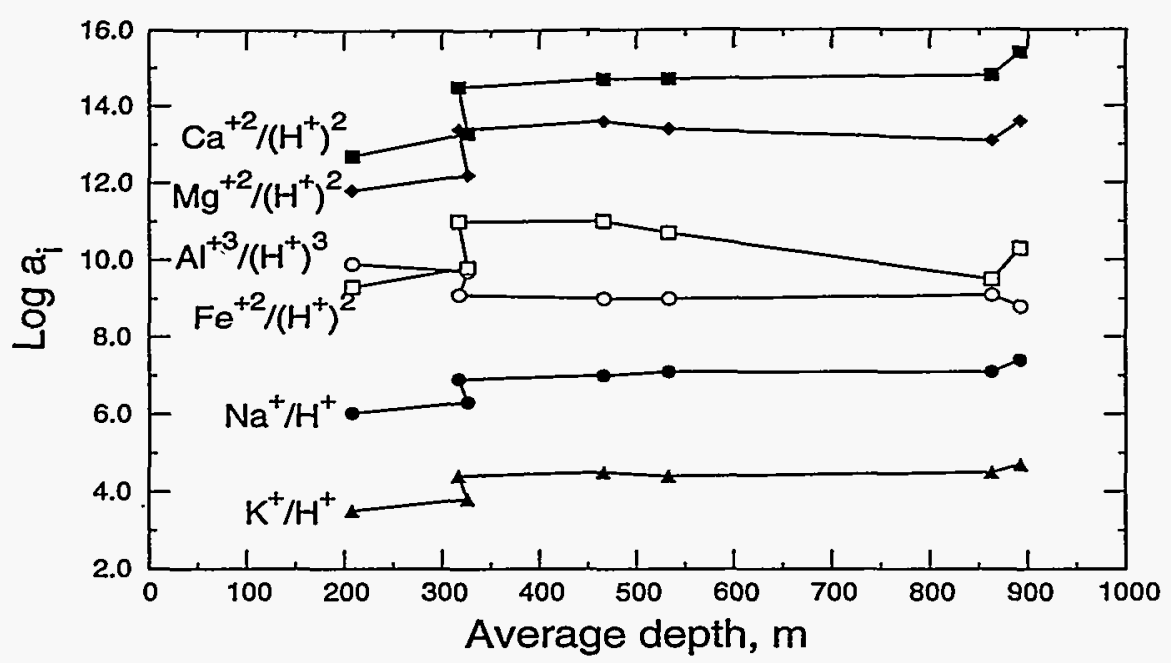

Figure 2. Logarithm of ratios of ion activities to hydrogen activity as a function of average depth of water sample in borehole KASO2.

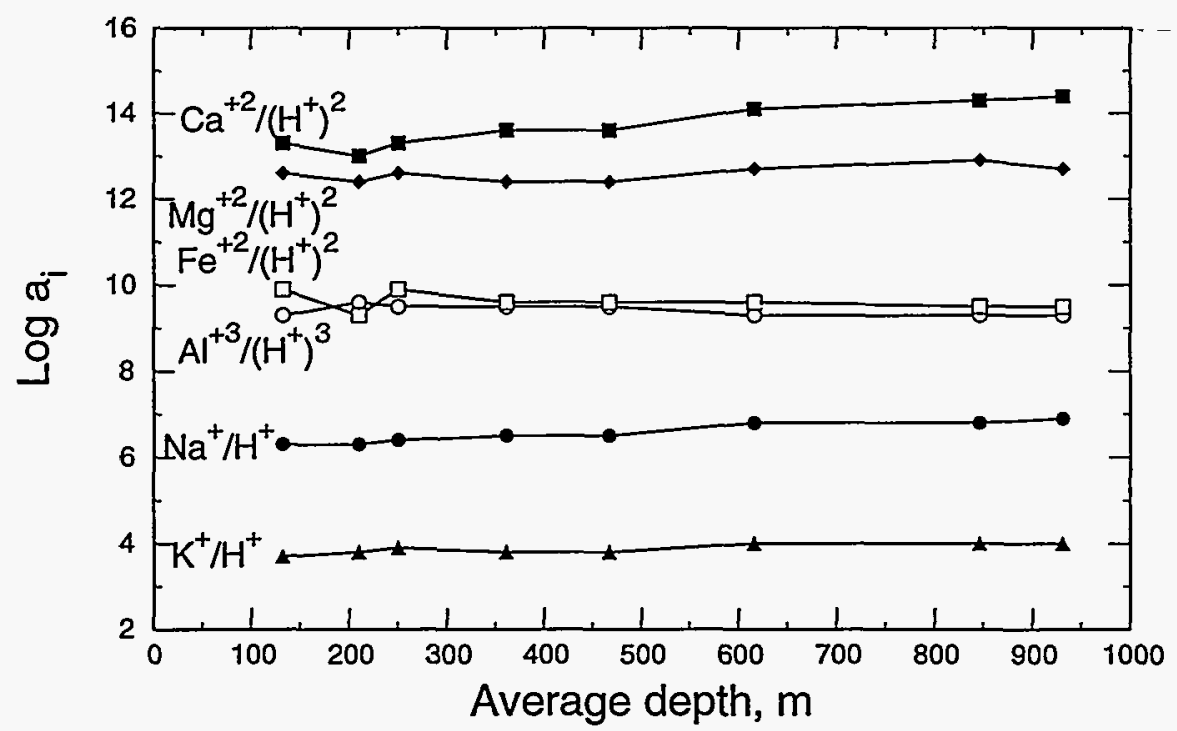

Figure 3. Logarithm of ratios of ion activities to hydrogen activity as a function of average depth of water sample in borehole KASO3.

\section{Redox calculations}

Another set of runs for borehole KAS02 explored the implications of using the measured sulfide and sulfate concentrations to constrain the Eh of the sulfur system, while retaining the use of measured Eh to constrain all other redox potentials in solution. The differences in the Eh and the logarithm of the fugacity of oxygen gas $\left(\log \mathrm{fO}_{2}\right)$ calculated from the sulfide/sulfate concentrations (calc.) and that measured (meas.) were relatively minor. For example, in the 202-214 $\mathrm{m}$ depth range, Eh(calc.) $=-0.22$, Eh(meas.) $=-0.26, \log$ $\mathrm{fO}_{2}($ calc. $)=-71.9, \log \mathrm{fO}_{2}$ (meas. $)=-74.7$. In the 860-924 $\mathrm{m}$ depth range, 


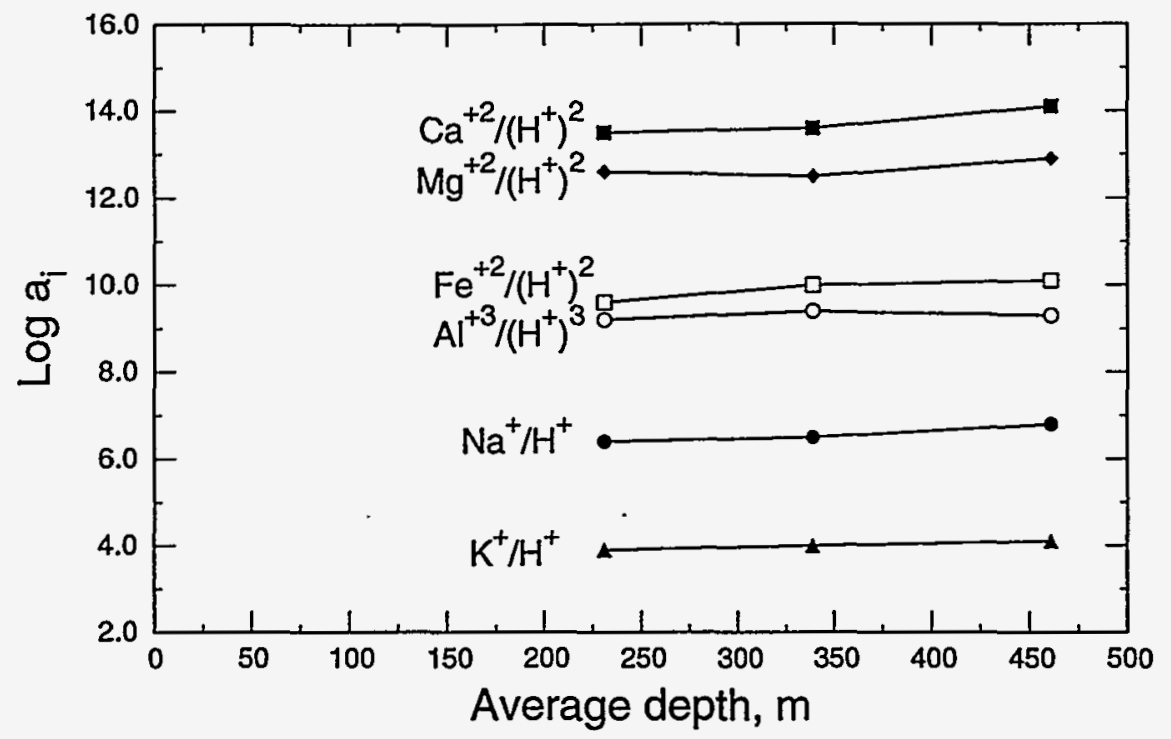

Figure 4. Logarithm of ratios of ion activities to hydrogen activity as a function of average depth of water sample in borehole KASO4.

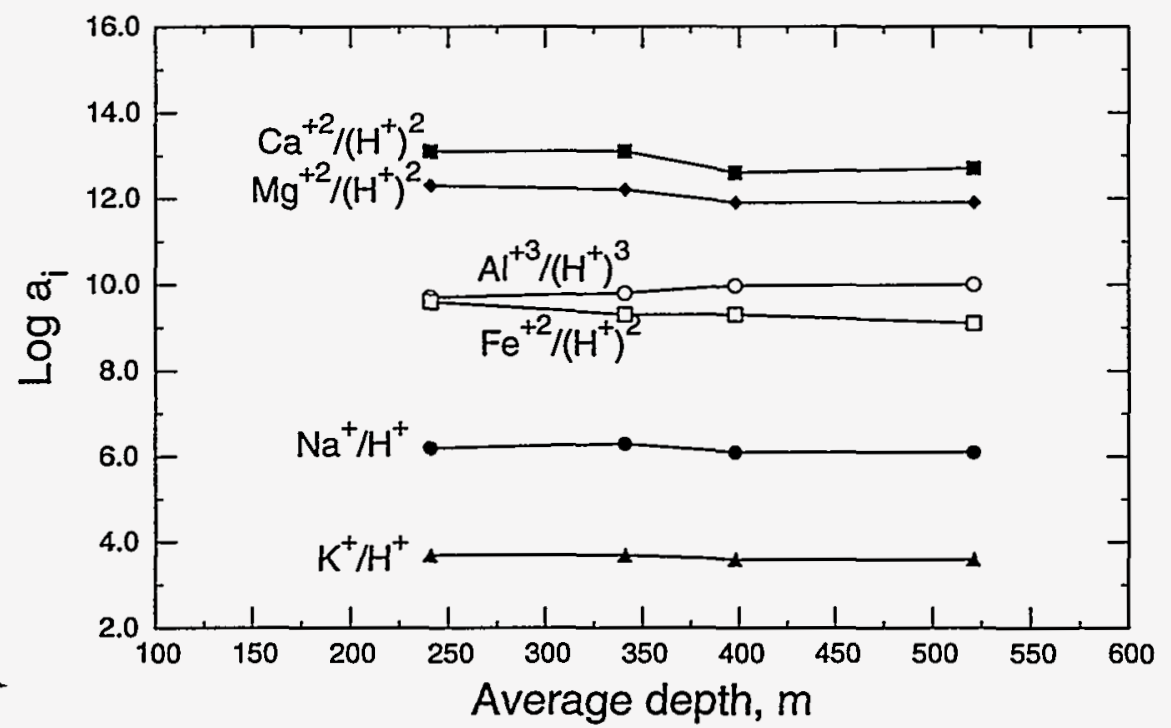

Figure 5. Logarithm of ratios of ion activities to hydrogen activity as a function of average depth of water sample in borehole KASO6.

$\mathrm{Eh}$ (calc.) $=-0.29, \mathrm{Eh}$ (meas.) $=-0.32, \log \mathrm{fO}_{2}$ (calc.) $=-72.4, \log \mathrm{fO}_{2}$ (meas.) $=-74.5$. With regard to its impact on calculated mineral saturation indices, the mineral of interest most affected was, obviously, pyrite. Pyrite's saturation index was reduced in $\mathrm{KASO2}$, but remains significantly supersaturated in the waters. 
At the measured Eh and pH conditions of the 202m KASO2 Äspö water, C (graphite) is stable. Graphite might be considered as a proxy for a reduced organic carbon source. Eh$\mathrm{pH}$ diagrams reveal that the Äspö groundwaters lie in a narrow range very close to the $\mathrm{C}$ (graphite)- $\mathrm{HCO}_{3}{ }^{-}$equilibrium boundary, although only in the $202 \mathrm{~m}$ sample do the conditions correspond to those in the graphite stability field.

\section{Conclusions}

The above exercises test of the ability of the equilibrium mineral precipitation/dissolution models in EQ3/6 to accurately represent fluid-mineral equilibria in natural systems at low temperatures. The calculations suggest that at low temperatures (e.g. $25^{\circ} \mathrm{C}$ or lower) in shallow natural systems, the compositional characteristics of fluids are not controlled entirely by equilibrium mineral precipitation/dissolution, but by some combination of partial equilibrium, kinetics, ion exchange and surface reactions. Calculations of mineral saturation indices by themselves are of limited utility. Solution chemistry can, however, be used to try to identify and evaluate the reactions that produce observed solution compositions. In addition, as noted by Smellie and Laaksoharju (1992), solution chemistry is critical to predictions of radionuclide behavior and transport in the subsurface.

\section{Acknowledgments}

This work was performed under the auspices of the U.S. Department of Energy by Lawrence Livermore National Laboratory under contract W-7405-ENG-48. Financial support for this project was provided by the Geochemical Modeling activity of the Hard Rock Laboratory (HRL) Project Agreement between the U.S. Department of Energy and the Swedish Nuclear Fuel and Waste Management Company.

\section{References}

Fournier, R.O., 1983, A method of calculating quartz solubilities in aqueous sodium chloride solutions: Geochim. et Cosmochim. Acta, v. 47, p. 579-586.

Helgeson, H.C., Garrels, R.M. and MacKenzie, F.T., 1969, Evaluation of irreversible reactions in geochemical processes involving minerals and aqueous solutions- $\Pi$. Applications: Geochim. et Cosmochim. Acta, v. 33, p. 455-481.

Johnson, G.K., Tasker, I.R., Flotow, H.E. and O'Hare, P.A.G., 1992, Thermodynamic studies of mordenite, dehydrated mordenite, and gibbsite: Am. Min., v. 77, p. 85-93.

Laaksoharju, M., 1993, GEOTAB data obtained from disk supplied by M. Laaksoharju, 12/20/93.

Smellie, J. and Laaksoharju, M., 1992, The Äspö Hard Rock Laboratory: Final evaluation of the hydrogeochemical pre-investigations in relation to existing geologic and hydraulic conditions: Svensk Kärnbränslehantering AB, SKB Technical Report 92-31. 
Viani, B.E., and Bruton, C.J., 1992, Modeling fluid-rock interaction at Yucca Mountain, Nevada: A progress report: Lawrence Livermore National Laboratory Report UCRL-ID109921.

Viani, B.E., and Bruton, C.J., 1994, Effect of cation exchange on major cation chemistry in the large scale redox experiment at Äspö: in Wikberg, P. and Banwart, S., eds., Proceedings of The Äspö International Geochemistry Workshop, June 2-3, 1994, Äspö Hard Rock Laboratory, Swedish Nuclear Fuel and Waste Management Company, SKB, Stockholm.

Walther, J.V. and Helgeson, H.C., 1977, Calculation of the thermodynamic properties of aqueous silica and the solubility of quartz and its polymorphs at high pressures and temperatures: Am. Jour. Sci., v. 277, p. 1315-1351.

Wolery, T.J., 1992, EQ3NR, A computer program for geochemical aqueous speciationsolubility calculations: Theoretical manual, user's guide, and related documentation (Version 7.0): Lawrence Livermore National Laboratory Report UCRL-MA-110662 PT III.

Wolery, T.J. and Daveler, S.A., 1992, EQ6, A computer program for reaction path modeling of aqueous geochemical systems: Theoretical manual, user's guide, and related documentation (Version 7.0): Lawrence Livermore National Laboratory Report UCRL-MA110662 PT N. 


\section{DISCLAIMER}

This document was prepared as an account of work sponsored by an agency of the United States Government. Neither the United States Government nor the University of California nor any of their employees, makes any warranty, express or implied, or assumes any legal liability or responsibility for the accuracy, completeness, or usefulness of any information, apparatus, product, or process disclosed, or represents that its use would not infringe privately owned rights. Referenceherein to any specificcommercial products, process, or service by trade name, trademark, manufacturer, or otherwise, does not necessarily constitute or imply its end orsement, recommendation, or favoring by the United States Government or the University of California. The views and opinions of authors expressed herein do not necessarily state or reflect those of the United States Government or the University of California, and shall not be used for advertising or product endorsement purposes. 